\title{
3 Information Literacy and Learning
}

Sirje Virkus

Albert K. Boekhorst

José A. Gomez-Hernandez

Annette Skov

Sheila Webber

\section{Introduction}

This chapter is based on discussions which took place in the virtual workshop and the face-to-face (F-2-F) workshop on information literacy and learning. The virtual forum took place from May to August 2005 and face-to-face workshop on August 11-12, 2005 in Copenhagen. The goal of the workshops was to discuss the most relevant issues on the topic "Information Literacy and Learning" in connection with Library and Information Science (LIS) curriculum in the context of the Bologna process. The structure and logic of the virtual and F-2-F workshops were similar in all twelve workshops within the SOCRATES-funded project "LIS Education in Europe: Joint Curriculum Development and Bologna Perspectives". The list of the members of the virtual and F-2-F workshop group on information literacy and learning is included as Appendix 1.

The participants of the workshops addressed the following questions:

- How should we define information literacy (IL) in connection with LIS curriculum?

- How should IL be positioned in LIS curriculum?

- How should learning to become "information literate" and learning to facilitate learning of IL be delivered in LIS schools?

- What topics form the curriculum for IL and learning?

- What approaches, strategies and actions have LIS schools implemented in integrating/embedding IL into LIS curriculum?

- What are the examples of best practice of facilitating IL within the LIS curriculum?

- How has the Bologna process influenced IL and LIS curriculum in different countries?

- What communication and networks for LIS educators in IL domain exist?

- What kind of research agenda we need in connection with IL and LIS curriculum?

The topics discussed in the virtual and F-2-F workshops are reflected in the following sections: the definition and importance of information literacy, how learning to become "information literate" and learning to facilitate learning of IL should be delivered in LIS schools, what topics form the curriculum for IL and learning, examples of IL practice, communication and networks for LIS educators in IL domain and research agenda for IL. 


\section{Definition of information literacy}

The members of the virtual forum agreed that a broad definition of IL from the Prague Declaration, the Chartered Institute of Library and Information Professionals (CILIP), the American Library Association (ALA), Webber and Johnston or Boekhorst were most useful in general and as a working definition for the purpose of the forum.

For example:

"Information Literacy encompasses knowledge of one's information concerns and needs, and the ability to identify, locate, evaluate, organize and effectively create, use and communicate information to address issues or problems at hand; it is a prerequisite for participating effectively in the Information Society, and is part of the basic human right of life long learning" (Information Literacy Meeting of Experts, 2003)

"Information literacy is knowing when and why you need information, where to find it, and how to evaluate, use and communicate it in an ethical manner" (CILIP, 2005).

"To be information literate, a person must be able to recognise when information is needed and have the ability to locate, evaluate, and use effectively the needed information" (American Library Association, 1998)

"Information literacy is the adoption of appropriate information behaviour to obtain, through whatever channel or medium, information well fitted to information needs, together with critical awareness of the importance of wise and ethical use of information in society" (Johnston and Webber, 2003).

“... all these literacies [basic literacy, scientific literacy, technological literacy, visual literacy, cultural literacy] can be considered as specific competences that belong under the information literacy umbrella. Therefore information literacy should be considered as a container concept, which refers to competences of people to recognize the need for information and to satisfy their information needs for survival, self-actualisation and development" (Boekhorst, 2003a).

Boekhorst (2003a) summarises the definitions and descriptions which have been presented over many years into three concepts: (1) the ICT concept; (2) the information (re)sources concept; and (3) the information process concept. However, not all participants agree with his statement and argue that these three concepts do not include all dimensions of IL.

It was also agreed that the term 'information literacy' is the wider and more suitable term than 'information skills' to carry the meaning of the concept.

Thus, the working definition of IL that guided discussions in the virtual forum on IL and learning was broad, and could be seen as an umbrella definition that included many other literacies and implied business as well as private life in the context of lifelong independent and flexible learning. 


\section{Importance of information literacy}

It was agreed that IL is absolutely critical literacy to all sectors of society and that it enables people to cope successfully in their professional and personal lives and benefit from the knowledge society. Boekhorst (2003b) highlights the technization, differentiation and globalisation process of our modern society and notes that in this process we see the following effects related to information flows: (1) a exponential growth of information, information media, information channels and information services (2) a growth of technology, tools and applications to retrieve, process and disseminate information (3) changes in communication patterns and behaviour. Thus, while people move forward through time and space (Dervin \& Nilan, 1986) they need knowledge: knowledge on themselves and on their social and technical surrounding. While moving forward people are confronted with the fact that their knowledge is not enough to go on with their activity, to make decisions or start a new activity. There is a knowledge gap and an information need. Such a situation can arise because something changes in a person or in his or her surroundings. Depending on the importance of the situation and the degree of uncertainty, a person will search for information to satisfy an information need, to reduce uncertainty and update his or her knowledge. In this way people can survive, develop themselves, perform tasks and relax.

The process of recognising and identifying an information need, and of locating, accessing, retrieving, using and disseminating information has been presented by Boekhorst (2003b) in the following way in Figure 1

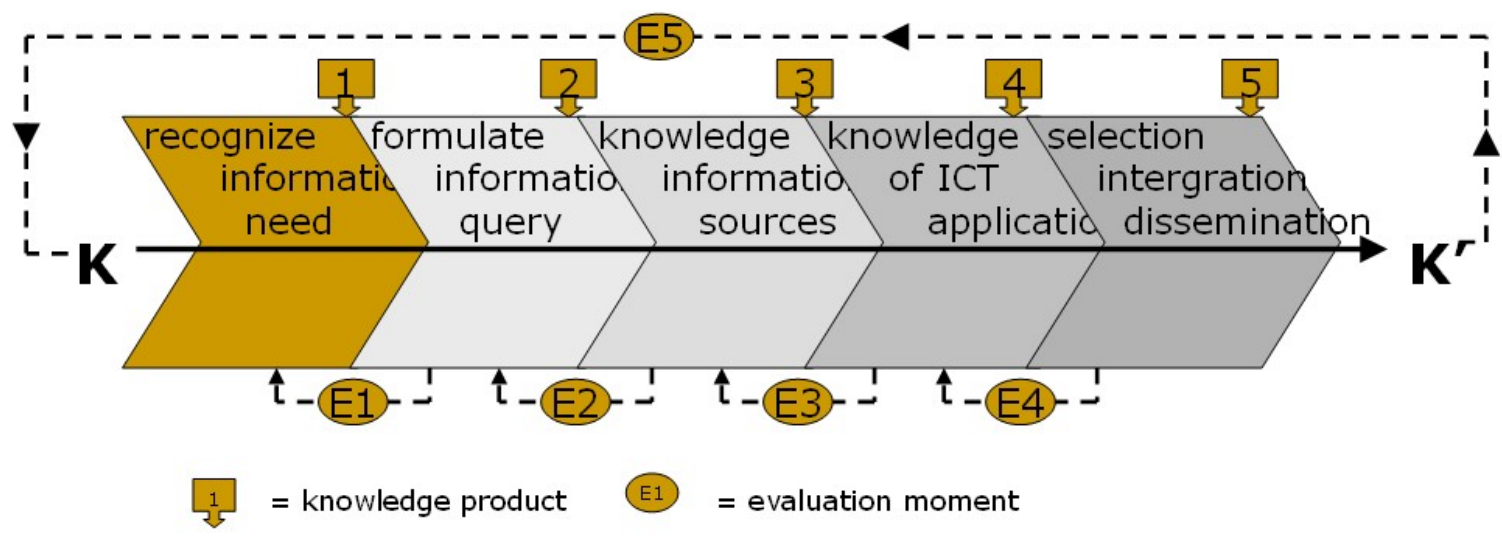

Figure 1. Information literacy model

Boekhorst (2003a) also provides a framework for information literacy/illiteracy in information-rich versus information-poor contexts. 


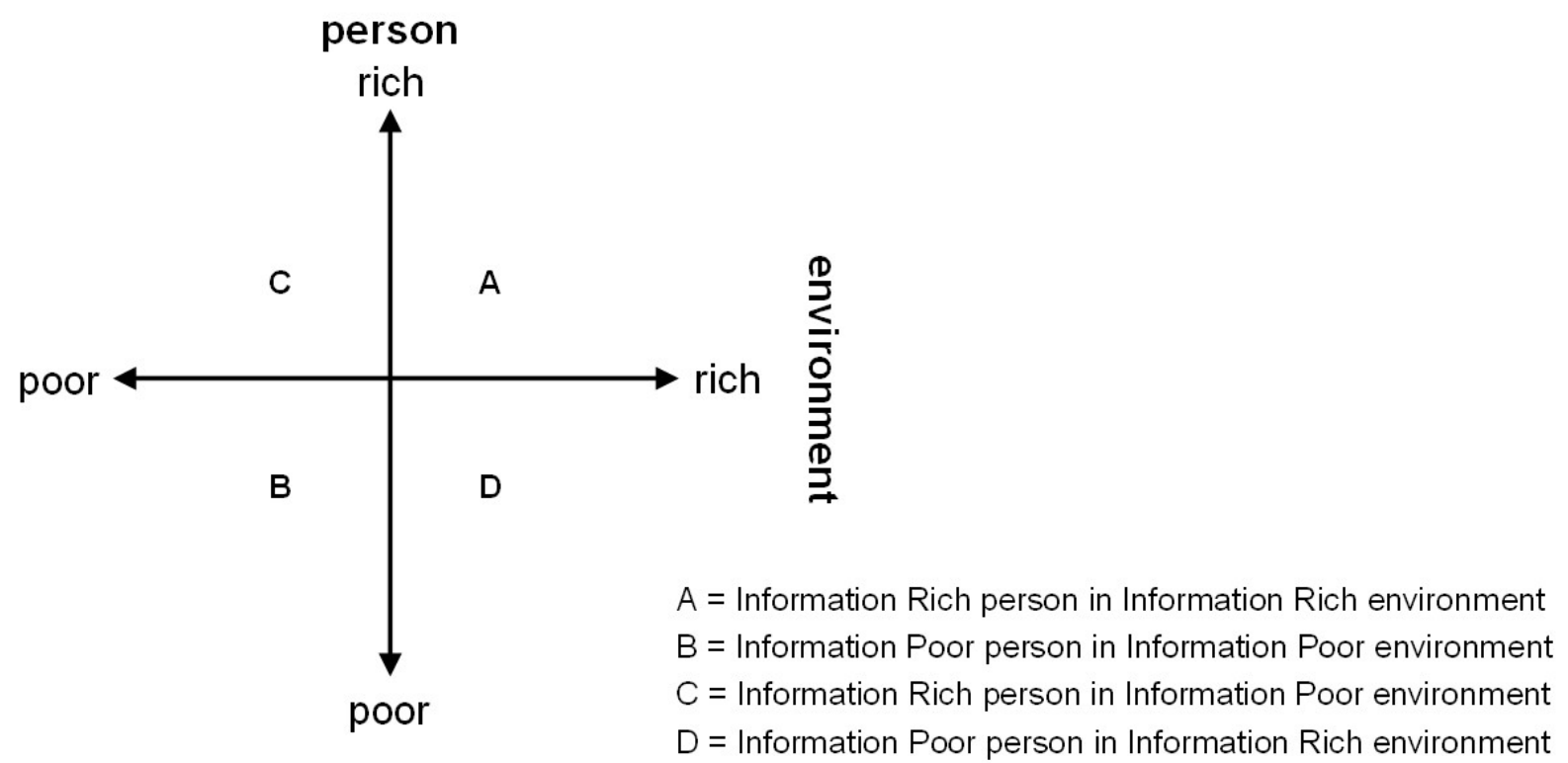

Figure 2 Information Rich - Information Poor

Boekhorst (2003a) notes that being information literate must be learned. 'Parents' are the first who implicitly and explicitly facilitate their children's learning of information. Becoming information literate should continue at primary school and be a part of formal training in all phases and all subject areas during the whole education process as a preparation for lifelong learning. Although a difference can be made between content and conduit, becoming information literate can only be learned effectively in context. Therefore in each phase of schooling in each subject explicit attention has to be given to IL aspects. In this way students are prepared for a lifelong learning process. That means that all educational staff have to learn how to integrate IL into their teaching.

\section{The teaching and learning of information literacy within LIS curriculum}

Library and information professionals too have a specific function in the process in which people become information literate. They facilitate access to information and help people to satisfy their information needs. Facilitating people to become better independent information users is one of their tasks. They too have to learn to do this effectively.

It was contended that it is essential for LIS students:

1. To be aware of information literacy as a concept;

2. To become information literate themselves;

3. To learn about some key aspects of teaching information literacy.

It was highlighted that being information literate is a necessity for information professionals because it helps them maintain a lifelong learning attitude that keeps them abreast of an ever changing information environment, while at the same time it enables 
them to develop as facilitators of learning to help users become information literate. LIS students need to understand THEMSELVES as information literate people, and understand IL holistically, before they can start teaching someone else about it. Perhaps some educators have an underlying assumption that LIS students become information literate by studying library and information science? It's not necessarily so!

IL itself may be taught through a separate class, or may be covered explicitly in one or more other LIS classes (e.g. together with Information Retrieval or Knowledge Management), or may be seen as an approach to learning which is used in another class, or may be addressed as part of a class which focuses on how to teach IL. Different lecturers as well as workshop members argue in favour of one approach or another, but there are successful examples of all these strategies. Decisions on which option is adopted will probably be based on factors such as: the objectives of the whole programme, the length of the programme, the national/institutional context and priorities, the nature of the student body, and the teacher's pedagogic approach and philosophy.

Whatever the model preferred, teaching and learning methods should reflect the essence of IL. It is often said that IL is about learning and learning how to learn; the teaching and learning of IL should reflect this. The teaching of IL should be a model for good teaching practices; to teach IL using a spoon feeding, passive knowledge-transmitting approach is self-contradictory. As IL is all about critical analysis, independent learning, problemsolving, reflective thinking and ethical use of information, an inquiry-driven, knowledge construction approach exposing students to a "deep approach" to learning is the most appropriate.

Annette Skov summarises discussions in the forum and her experiences in teaching IL as a number of guidelines for designing a learning environment for IL that can be derived from these principles:

- It should allow students to be at the centre of the learning process engaging with learning resources in an active and reflective way. The learning environment should provide room for reflection: reflection on IL issues, and self-reflection on learning experiences and progress. Teaching is about getting a "hook" into the individual student's life project; by encouraging reflection, students are asked to consider: is this learning experience important to my life project? What can I learn that will prove useful to me in the future and help me accomplish my goals?

- A number of topics in the IL curriculum lend themselves to active investigation; reading about theories is useful, but being actively involved with theories is even more useful. For instance, the concept of learning styles is usually a topic addressed in IL teaching. Let students work in teams organised according to different learning styles. Kolb's theory on the Experiential Learning Cycle shows that people learn through concrete experience, reflective observation, abstract conceptualisation and active experimentation. Let students be exposed explicitly to this way of planning a learning experience. Schön's "The reflective 
practitioner" and "reflection-on-action" can be studied in a textbook, but why not invite reflective practitioners to share their reflections with students?

- Students' past experiences should be recognised and discussed - they have been learners most of their lives, and they bring with them a body of knowledge on their own learning histories that should be drawn upon, discussed and challenged.

- The acquisition of "additional" competences should be encouraged. ICT competences can be enhanced by creating digital portfolios; social and communicative competences by engaging in collaborative work; network competences by taking part in virtual learning environments; and problem solving competences by adopting a problem based learning approach.

- Project work should be concerned with real-life situations and problems. If the objective is to teach students to facilitate learning of information literacy, they should plan a teaching sequence, outlining choice of target group and topic, learning environment, perception of learning, pedagogical and didactic considerations - and actually teach the sequence.

- The lecturer teaching IL should be a designer of the learning environment, a guide on the side, a coach and a motivator, and not a transmitter of knowledge.

An assessment is a necessary element of IL. The assessment practice should be aligned with the pedagogical thinking underpinning the teaching and learning of IL, and appropriate for the learning outcomes that have been set for the assignment or module. Assessments can be formative or summative; as students' reflections on their learning processes are considered important, formative assessment should be used to give feedback to students. A room for reflection can be created quite literally by asking students to create digital portfolios or weblogs to host their assignments and reflections. The summative assessment should assess both the process and the products, i.e. the student's learning process and self-reflection, and the accomplishment of the products in terms of learning outcomes. Critical self-evaluation and self-assessment of performance is an essential quality of the lifelong learner. Unless students are encouraged to take at least some responsibility for their own assessment they are unlikely to reach their full potential as creative, productive learners in the workplace or community. This requires, however, that students are involved in setting and understanding criteria for assessment (Candy et al, 1994).

\section{Topics forming the curriculum for information literacy and learning}

The depth of coverage of IL topics will vary depending on the nature of the course. Sheila Webber summarises firstly key topics for IL, and secondly topics concerned with the subject of teaching IL. In doing this she referred to key frameworks for IL drawn up by 
professional associations, discussions in the virtual and F-2-F forums, and selected LIS curricula in information literacy and learning.

\section{Curriculum for Information literacy}

A number of associations have produced detailed frameworks describing desired characteristics or outcomes for the information literate person. These include the ACRL (Association of College and Research Libraries, 2000) Information Literacy Competency Standards for Higher Education developed in the United States, the Australian and New Zealand Information Literacy Framework (Bundy, 2004) and the Seven Pillars of Information Literacy model produced by the United Kingdom's Society for College, National and University Libraries (SCONUL Task Force on Information Skills, 1999). The ACRL standards have also been translated into other languages (e.g. Homann, 2002) and at time of writing the Information Literacy Section of the International Federation of Library Associations and Institutions (IFLA) was about to publish an international manual for IL. Some of these documents, in particular the ACRL standards go into a good deal of detail about the desired learning outcomes for an information literate person, and that material is not duplicated here. Instead the areas covered by all the key standards are highlighted, as follows.

The LIS student should:

- Be able to recognise when he/she needs information, to identify the nature of the information need, and what the gap is between what he/she knows and what he/she needs.

- Be aware of what different channels and sources are available, be able to identify the appropriate resources for a particular information need, and use these resources effectively to acquire the needed information.

- Be able to evaluate information effectively.

- Be able to manage and apply information.

- Be able to synthesize information and use it to create new knowledge and understanding.

- Be aware of the cultural, ethical, economic, legal, and social issues surrounding the use of information.

Additional important skills, knowledge and attitudes are highlighted in other prominent statements, for example the Prague Declaration (Information Literacy Meeting of Experts, 2003), or were identified as important for LIS students in discussion that took place as part of this project. These skills, knowledge and attitudes are summarised as follows:

The LIS student should:

- Understand key definitions and models of IL, including similarities and differences between them;

- Be aware of different contexts (e.g. social life, workplace, education, private life) for information literacy, and understand the implications for IL in these different contexts; 
- Be able to distinguish the relationship of IL with other literacies (e.g. media literacy, IT literacy) and understand the importance of basic literacy skills in underpinning IL;

- Understand the relationship between IL and other LIS skill and knowledge areas (e.g. Knowledge Management, Information Retrieval);

- Understand the research base for IL: understanding key models and theories (e.g. Bruce's (1997) 7 faces model) and being aware of appropriate research approaches;

- Know the functions and scope of key IL organisations and initiatives in the student's country;

- Be aware of the history and origins of IL.

\section{Curriculum for teaching information literacy}

Pedagogy and andragogy are significant subjects in their own right, and LIS educators will probably only be able to cover selected aspects, unless pedagogy is a major focus of an LIS programme. LIS educators will also want to refer to educational texts of relevance to specific countries and levels (e.g. Biggs, 2003, would be a good text for educators of UK academic librarians) as well as specialist LIS texts (e.g. Grassian, 2001; Iannuzzi, 1998; Webb and Powys, 2004). The TUNE (Training of Library Users in a New Europe) project identified desirable attitudes and personal competencies for librarians: for example that they should be open-minded, flexible, user-oriented, have social communication abilities and the ability to work collaboratively (TUNE, 2005). These may be seen as desirable qualities for all LIS students, but they are certainly essential for LIS students who are going to teach IL.

The following topics were identified through discussion, and examination of some existing courses and texts.

1. Curriculum design and planning, including:

- identifying learners' needs;

- developing appropriate learning outcomes to meet those needs;

- understanding and applying appropriate modes of assessment;

- aligning teaching, learning and assessment in course design;

- understanding appropriate use of technology in designing learning environments;

- evaluating IL courses and training sessions, including those delivered online.

2. Understanding learners and learning theory, including:

- learning models and theories, including learning styles, learning strategies and elearning models;

- needs and characteristics of particular types of learner e.g. distance learners, elearners, adult learners, learners with special needs;

- information behaviour and IL research providing insight into the conceptions or educational needs of learners.

3. Understanding basic concepts, theories and practice of teaching, including: 
- conceptions of, and approaches to, teaching;

- teaching methods and tools, including use of technology;

- collaborative teaching, including issues concerning collaboration with specific groups e.g. collaboration between librarians and academics in teaching.

4. Understanding the context for teaching and learning, including:

- awareness of education policy and practice in specific countries/sectors;

- the place of learning in a citizen's life, and the concept of lifelong learning;

- understanding key issues concerned with teaching IL in particular sectors (e.g. schools, higher education, companies, museums, health, public libraries);

- understanding issues concerned with the teaching and learner support role of the librarian;

- understanding the role of IL in relation to other library and information services;

- understanding how LIS professionals can communicate the benefits of IL education to their users.

The Euroguide Competencies and aptitudes for European information professionals (European Council of Information Associations, 2004), does include a section M08: Management of education and training (p56). However, it was agreed by the forum members that this covers only some of the topics listed above, focusing principally on management and delivery issues.

\section{Relationship with other LIS subjects}

There are links between Information Literacy and other LIS subjects, most notably with Human Information Behaviour. Some research is important to both areas (e.g. the work of Kuhlthau) and there are common practical outcomes (e.g. effective information searching). This may result in, for example, models of information behaviour being taught in an information literacy class, or elements of both IL and information behaviour being taught in an information retrieval class. There are also links with management and marketing (e.g. in identifying user needs, in managing and planning a service, and in understanding the organisational context and mission). IL has been identified as essential to Knowledge Management (Abel and Oxbrow, 2001) and could be learnt about in that context. Issues to do with lifelong learning and educational policies could be taught in classes concerned with the information society. Additionally, there are some competencies relevant to teaching IL which may be seen as part of a librarian's overall professional competencies e.g. technological competencies; communication skills.

\section{Examples of information literacy practice in LIS curriculum}

The participants of the virtual forum described their experiences in the following way; for example, Susie Andretta from the London Metropolitan University, UK notes:

My experience of IL is that unless it is fully integrated within the LIS curriculum (as a core element at both undergraduate and postgraduate levels) then its impact will not be as 
effective as one would wish. In the School of Information Management at London Metropolitan University we have introduced IL as part of the research methods module (which is a core unit of all our pg courses). IL here is complemented by the action research approach (as these two perspectives promote reiterative and reflective learning) in the module called: Applied Information Research (AIR) where the independent learning competences of IL are fully embedded in a real-world research context. The development of AIR was generated as the result of a consultation exercise with information professionals where a 'can do' attitude was identified as a priority, together with competences in communication and knowledge of sources. We have interpreted a "can do attitude" as the development of an independent learning approach because, in our view, this process necessarily underpins the problem-solving strategies encountered in any information practice.

In my view being information literate is now a necessity for IPs because it helps them maintain a lifelong learning attitude (by embracing the learn-how-to-learn approach) that keeps them abreast of an ever changing information environment, while at the same time it enables them to develop as facilitators of learning to help other users become information literate.

The idea of introducing IL as part of the research competences that Information Professionals (IPs) should develop is fully supported by the literature (Bruce and Moore in particular advocate this) and from experience it has worked well in fostering independent learning attitudes in IPs who attend the AIR module. Not surprisingly, evidence have shown a substantial improvement in students' performance in the dissertation. However, a totally unintentional (but welcome) outcome generated by the IL practice in AIR is the increase in the professional confidence that most of our student (especially those working in public and academic libraries) have experienced as a result of this provision.

Unlike the enthusiastic response that Annette refers to IL in the UK is still not fully acknowledged as a core element of IPs practices. This is why it is so important to ensure that IL is fully integrated in any LIS curricula and Continuing Professional Development policies [forum message, 15/06/05]

\section{Sheila Webber summarises key points about three classes at Sheffield University's} Department of Information Studies, UK:

One class "Information Literacy" is a level 1 semester 1 compulsory component of our BSc Information Management. Key learning outcomes are for the students to analyse their own information behaviour and start to identify ways in which they can become more information literate, to understand some key information literacy models and theories, and to develop some specific skills (e.g. oral presentation skills and searching skills). The main piece of assessed coursework asks the student to reflect on his/her progress in information literacy, presenting relevant evidence, and using the framework of the SCONUL "7 Pillars of Information Literacy." The class involves a large amount of interaction and activity in pairs and groups. In particular, student groups work over several weeks on the solution to a meaningful information problem which they then present orally, and also students pair up to set each other search topics which have to be mindmapped, carried out, documented and presented as evidence for their assessed work. Following on from this class, information literacy is progressed at other points in their degree programme. For example, a level 2 class focuses on Information searching and retrieval, and another class which focuses on 
knowledge management, where the relevance of information literacy to KM and to the learning organisation is explored.

Our postgraduate MA Librarianship students have a compulsory module "Information Resources and Information Literacy" which similarly requires them to reflect on their achievement in information literacy, and also asks them to carry out a search on a specified topic and present a bibliography. Later in the course, as one of their optional classes, they can choose "Educational Informatics". This introduces key pedagogical principles and theories, before focusing on issues and tools to do with the use of technology to support learning, teaching and assessment. Students in this class form groups, each of which designs a WebCT module, and they also produce written documents relating to this task.

Annette Skov from the Royal School of Library and Information Science in Copenhagen, Denmark, describes her IL course:

Libraries are facing a number of exiting educational and pedagogical challenges; for example, lifelong learning and the information literate citizen in the knowledge society. It is the library sector's job $(+)$ to support these aims via user education from "craddle to grave" in collaboration with other stakeholders.

Teaching has become a professional competence, no matter if one is employed as a childrens' librarian, an academic librarian, or working in the private sector. The objectives of this course is to enable students to plan, design and deliver instruction, both in the physical and in the virtual learning environment. The course has both a theoretical and a practical aim. The point of departure is theories on learning, learning styles and multiple intelligences, focusing on their significance for designing learning environments.

Not all developments have been influenced by IL efforts. For example, in Estonia, the ICT-based education and distance education has directed towards the IL road. For example, Sirje Virkus from the Department of Information Studies of Tallinn University notes:

.... since 1994 we have started step by step to develop of our students' knowledge, skills and understanding in reflective thinking, critical analysis, problem-solving, learning-tolearn, teamwork, presentation, etc. and we have presented these efforts at conferences and in journals talking about 'new pedagogical models' or the move from 'knowledge transfer model' to 'knowledge construction model' at our department. It meant that we drastically decreased the amount of lectures and focused more on team-projects requiring problem solving and on reflective seminars in all areas of curriculum to develop complex cognitive skills and social competences of our students. However, these ideas derived not from IL efforts, but rather from educational theories and collaboration with high level DE centres and institutions (for example, Pennsylvania State University, University of New Brunswick, the Dutch Open University, EADTU) and experts (for example, Michael Moore, Elizabeth Burge, Martin Valcke, Rob Koper, etc.) when the Department started to develop its DE programmes based on modern ICT.

Thus, being influenced by constructivist and reflective thinking (Jonassen, Schön, etc.) and alternative modes of educational delivery we started to rethink our curriculum, our pedagogical or didactic models but we didn't think then in terms of IL. We started close cooperation with the department of educational sciences and computer sciences in 
developing joint project proposals and arranging joint research seminars and it influenced our thinking as well. Thus, I should confess that focus on distance learning and virtual learning environments influenced our understanding of new ways of curriculum design. Our own university supported this approach, finding that products like WebCT or Blackboard has no constructivist logic built in and our Educational Technology Centre developed learning management system IVA based on open source and derived from the so called 'three Cs model' of Jonassen (Context, Collaboration, Construction) that fosters the constructive way of learning and teaching. Andragogy (taught by the Chair of Andragogy within the Department of Educational Sciences) and user education have been in our LIS curriculum more than 15 years.

Thus, now we can talk about the following aims of our curriculum:

a) to foster graduates to achieve qualifications and competencies needed for work in information sector;

b) to foster our students to become information literate and to undertake research;

c) to foster the development of knowledge, skills and attitudes needed for facilitating IL

[forum message, 20/06/05]

It should be also noted that there are several other examples of IL practice even those were not described very precisely in the virtual forum. For example "Information Literacy Instruction: Theory and Practice" class is offered at University College Dublin. Claire McGuinness notes:

"This course aims to introduce students to the theoretical foundations of pedagogy, and to explore with them, the various instructional options that are available to the "teaching librarian" in the modern context. Students will learn about the planning, design, delivery and assessment of information literacy instructional programmes, with the aim of preparing them for the type of teaching work they may undertake as part of their jobs."

\section{Communication and networks for LIS educators in this domain}

It should be noted that there is no European or international organization, institution or association for LIS educators whose main concern is IL within the LIS curriculum. However, many organizations, networks and associations at a global, regional and national level have promoted the issue of IL and made an invaluable contribution, both to thinking about IL and to the development of LIS curricula with an IL component. Communication and networking is also supported by many international projects, conferences and discussion lists. Thus, LIS educators in Europe have been active in IL initiatives in Europe as well as internationally (Virkus, 2003).

Perhaps, the best-known intergovernmental organization that has started the promotion of IL in the context of its Information for All Programme (IFAP) is the United Nations Educational, Scientific and Cultural Organization (UNESCO). During the 8th meeting of the Bureau of the Intergovernmental Council for the Information for All Programme, at UNESCO Headquarters in Paris, a Thematic Debate on Information Literacy took place on 5 April 2005. The purpose of the debate was to identify the particular contribution that IFAP could make to give all people the opportunity to become information literate. With 
the support of UNESCO several major IL initiatives have been arranged; for example, the Information Literacy Meeting of Experts in Prague in September 2003, UNESCO was also a co-sponsor of an international leadership colloquium on IL, which was held in Alexandria, Egypt, November 6-9, 2005.

UNESCO's main strategy in the area of IL consists of awareness-raising about the importance of IL at all levels of the education process - basic education, primary and secondary education, technical and vocational training and lifelong education - and of establishing guidelines for integrating IL issues in curricula. A particular focus will be on training teachers to sensitize them to the importance of IL in the education process to enable them to incorporate IL into their teaching and to provide them with appropriate pedagogical methods and curricula. European LIS educators have been invited as major experts to the meetings in Prague and in Paris.

The International Federation of Library Associations and Institutions (IFLA) focused its concerns regarding the teaching of IL through the establishment of a Roundtable on User Education in 1993. At their meeting during the IFLA Boston conference in August 2002, the Round Table changed its name to the Information Literacy Section. The primary purpose of the IL Section is to foster international cooperation in the development of IL education in all types of libraries. The Section focuses on all aspects of IL including user education, learning styles, the use of computers and media in teaching and learning, networked resources, partnerships with teaching faculty in the development of instructional programmes, distance education, and the training of librarians in teaching information and technical skills. It is the mission of the Section to disseminate information on IL programmes and trends and work closely with other IFLA bodies and other organizations in the development of programmes, workshops and projects related to IL education. Again, European LIS educators participate actively in this section. There are also some international associations with IL interests groups (for example, International Association of School Librarianship (IASL) Information Literacy Special Interest Group) but European LIS educators are not actively involved in those groups. Upon a recommendation from the Prague Meeting of Information Literacy Experts several organizations (e.g. Australian and New Zealand Institute for Information Literacy (ANZIIL), US National Forum on Information Literacy, NORDINFOlit, SCONUL Working Group on Information Literacy, etc.) are committing to creating an International Alliance for Information Literacy. The evolving purpose for the Alliance is to facilitate the sharing of information and expertise on IL across regions and nations of the world. The Alliance will consist of organizations that act as nodes around the world (National Forum on Information Literacy, 2005).

Professional organizations and associations in a number of countries or representing specific regions of the world have promoted the importance of IL. For example, in the USA, Australia and New Zealand professional associations have made an invaluable contribution to thinking about IL and contributed towards IL practice and developed standards and recommendations that have been influential both nationally and internationally. In Europe, the European Union has taken various initiatives supporting networking and communication in the IL area, though the lack of coherent and long-term policy is clear. For example, several IL projects with the involvement of European LIS 
educators have been funded by the EC - EDUCATE, DEDICATE, LOCOMOTIVE, DELCIS, etc. (Virkus, 2003).

There are also various IL initiatives in Europe where LIS educators are participating; for example, European Network for Information Literacy (ENIL) - a network of researchers focused on creating a common research agenda and exchanging best practices on IL; the European Network for School Libraries and Information Literacy (ENSIL); Library and Learning Support Working Group (LLSWG) of European Association of Distance Teaching Universities (EADTU) - a network for exchanging best practice and facilitating IL in European ODL institutions, the Nordic Forum for Information Literacy (NORDINFOlit) - a cooperative initiative of Nordic countries in the field of IL (Virkus, 2003).

At national level professional institutions and organizations in several countries have included IL in their agenda. For example, in UK, the Society of College, National and University Libraries (SCONUL) and the Chartered Institute of Library and Information Professionals (CILIP) have been the main promoters.

Several organizations and interest groups in Sweden work on and discuss the subject, for example Svensk Biblioteksförening with a special group for pedagogical issues at the library. In Denmark a number of special interest groups focus on IL. In the Netherlands, for example, LWSVO (National Workgroup of School Librarians in Secondary Education) assists school librarians in implementation of new developments in the school and school library. In Spain a working group on IL issues was set up in Cataluña under the name ALFINCAT. It includes a wide membership from other regions to exchange ideas, approaches and good practice, and the advancement and promotion of the IL agenda (Virkus, 2003). These are just few examples of national IL activities where LIS educators have been involved. The main activities of national institutions and organizations have been to arrange conferences and seminars, to share experiences and to facilitate thinking about IL among professionals.

Professional associations of LIS educators such as the European Association for Library and Information Education and Research (EUCLID) have recently started to pay more attention to IL issues as well. IL and learning is regarded as one main interest area within the LIS curriculum in the framework of the project "LIS Education in Europe: Joint Curriculum Development and Bologna Perspectives". However, it should be also noted that even the Bologna process has influenced several structural changes in European LIS education and also supported many earlier developments, its influence on the development of IL has not been significant.

\section{Research agenda for information literacy and LIS curriculum}

Several institutions, organizations (ACRL, 1980, 2000) and researchers (Bruce, 1997, Breivik, 2000) have proposed a research agenda for IL. For example, the ACRL Instruction Section (IS) Research and Scholarship Committee updated the document (the 
Research Agenda for Bibliographic Instruction by the ACRL Bibliographic Instruction Section (BIS) Research Committee, published in 1980) in 2000 and identified important research areas relevant to library instruction programmes in the current environment including IL. The Research Agenda for Library Instruction and Information Literacy was organized into four main sections: Learners, Teaching, Organizational Context, and Assessment. Each section poses general questions with the goal of encouraging those interested - practitioners, researchers, and students alike - to conduct research around these important areas.

Breivik (2000, p. xi-xii) identified a number of key issues that must be addressed if IL efforts are to be more effective and more extensive in the future. There was no evidence of mapping the research needed in the area of IL and LIS curriculum. However, the general areas reflected in the ACRL Agenda, as well as those identified by IL researchers, are also relevant to the LIS education domain. For example, to mention only a few:

- investigating the effectiveness of different methods of instruction for addressing various learning styles;

- understanding the impact of the Internet, as a teaching tool, on learning styles, and the implications for IL;

- investigating whether the structure and delivery of instruction differ when organized according to goals or concepts such as lifelong learning, subject-based teaching, course-integrated instruction, course-related instruction, or creditbearing library courses;

- exploring how an institution can ensure that librarians participating in IL efforts have the knowledge and skills to make the programme successful.

Thus, research into IL, and research in the educational domain in general, have a great impact on how we integrate/embed IL into LIS curriculum and facilitate both our LIS students' own learning in information literacy and these students' learning of how to facilitate others' information literacy.

\section{Conclusions and recommendations}

The following conclusions emerged from the discussion by some 18 participants:

- The working definition of IL in the framework of the LIS curriculum should be broad, and can be seen as an umbrella definition that includes many other literacies and implies business as well as private life in the context of lifelong independent and flexible learning.

- A broad definition of IL from the Prague Declaration, the CILIP, the ALA, Webber and Johnston or Boekhorst was the most useful in general and as a working definition for the forum.

- IL is absolutely critical literacy to all sectors of society that enables people to cope successfully in their professional and personal lives and benefit from the knowledge society. 
- IL is an ongoing process that should be facilitated throughout a whole life. Becoming information literate should start at home, continue at primary school and be a part of formal training in all phases and all subject areas during the whole education process as a preparation for lifelong learning.

- Library and information professionals have a special role in the process in which people become information literate. Thus, they have to learn to do this effectively.

- It is essential for LIS students: (a) to be aware of IL as a concept (b) to become information literate themselves (c) to learn about some key aspects of teaching IL.

- IL itself may be taught in different ways: through a separate class, or may be covered explicitly in one or more other LIS classes, or may be seen as an approach to learning which is used in another class, or may be addressed as part of a class which focuses on how to teach IL.

- Decisions on which option is adopted will be based on factors such as: the objectives of the whole programme, the length of the programme, the national/institutional context and priorities, the nature of the student body, and the teacher's pedagogic approach and philosophy.

- Whatever the model preferred, the essence of IL and constructivist approaches to learning and teaching should be reflected.

- The depth of coverage of IL topics will vary depending on the nature of the course. However, key topics for IL can de defined.

- There are no European or international organizations, institutions or associations for LIS educators which main concern is IL within the LIS curriculum. However, many organizations, networks and associations at global, regional and national level have promoted the issue of IL and made an invaluable contribution to thinking about IL as well as the development of LIS curriculum with IL component and European LIS educators have been active in those.

- Research into IL, and in the educational domain in general, have a great impact on how we integrate/embed IL into LIS curriculum and facilitate both our LIS students' own learning in information literacy and these students' learning of how to facilitate others' information literacy. However, the research agenda for IL and LIS curriculum still needs to be developed.

The following recommendations emerged:

- Promote and share experiences of good practice that stimulate LIS schools to integrate or embed IL into the LIS curriculum.

- Encourage collaboration amongst LIS educators to ensure IL is appropriately recognized as an essential element within the LIS curriculum

- Encourage coordination and collaboration with relevant international organizations, institutions or associations which concern is IL to avoid duplications and to create synergy. 


\section{References}

Abel, A. and Oxbrow, N. (2001). Competing with knowledge: the information professional in the knowledge management age. London: Library Association.

ACRL BIS Research Committee (1980). Research Agenda for Bibliographic Instruction. Retrieved 14 October 2005 from: http://www.ala.org/ala/acrlbucket/is/iscommittees/webpages/research/researchagend abibliographic.htm

ACRL IS Research and Scholarship Committee (2000). Research Agenda for Library Instruction and Information Literacy. Retrieved 14 October 2005 from: http://www.ala.org/ala/acrlbucket/is/iscommittees/webpages/research/researchagend alibrary.htm

American Library Association (1998). A Progress Report on Information Literacy: An Update on the American Library Association Presidential Committee on Information Literacy: Final Report. American Library Association, Chicago. Retrieved 15 October 2005 from: http://www.ala.org/ala/acrl/acrlpubs/whitepapers/progressreport.htm.

Association of College and Research Libraries. (2000). Information Literacy Competency Standards for Higher Education. Chicago, American Library Association. Retrieved 15 October 2005 from: http://www.ala.org/ala/acrl/acrlstandards/informationliteracycompetency.htm

Biggs, J. B. (2003). Teaching for quality learning at University. $2^{\text {nd }}$ ed. Milton Keynes: OU/SRHE.

Boekhorst, A. K. (2003a). Becoming information literate in the Netherlands. Library Review, 52 (7), 298-309.

Boekhorst, A. K. (2003b). Information Literacy in The Netherlands. On becoming Information Literate in The Netherlands. In: Carla Basili (ed) Information Literacy in Europe: a first insight into the state of the art of Information Literacy in the European Union. Roma: Consiglio Nazionale delle Ricerche, 187-205.

Breivik, P. S. (2000). Foreword. In: Bruce, C. and Candy, P. (eds) Information literacy around the world: advances in programs and research. Wagga Wagga: Charles Sturt University.

Bruce, C. (1997). The seven faces of information literacy. Adelaide: Auslib Press.

Bundy, A. (Ed.) (2004). Australian and New Zealand Information Literacy Framework: principles, standards and practice. ( $2^{\text {nd }}$ ed.) Adelaide: Australian and New Zealand Institute for Information Literacy. Retrieved 15 February 2004 from http://www.anziil.org/resources/Info $\% 201 \mathrm{lit} \% 202 \mathrm{nd} \% 20$ edition.pdf

Candy, P. C., Crebert, G. and O'Leary, J. (1994). Developing lifelong learners through undergraduate education. Canberra, ACT: Australian Government Printing Service.

CILIP (2005) Information Literacy: definition. London: CILIP. Retrieved 30 October 2005 from http://www.cilip.org.uk/professionalguidance/informationliteracy/definition/ 
European Council of Information Associations. (2004) Euroguide LIS: Volume 1:

Competencies and aptitudes for European information professionals. Paris:

ADBS Editions. Retrieved 15 October 2005 from: http://www.certidoc.net/en/eurefl-english.pdf

Grassian, E. and Kaplowitz, J. (Eds) (2001). Information Literacy Instruction: Theory and Practice. New York: Neal-Schuman.

Homann, B. (2002). Standards der Informationskompetenz: eine Übersetzung der amerikanischen Standards der ACRL als argumentative Hilfe zur Realisierung der 'Teaching Library'. Bibliotheksdienst, 36 (5), 625-638. Retrieved 15 October 2005 from: http://bibliotheksdienst.zlb.de/2002/02 05 07.pdf

Iannuzzi, P.; Mangrum, C. and Strichart, S. (1998). Teaching Information Literacy Skills. Boston: Allyn and Bacon.

Information Literacy Meeting of Experts. (2003). The Prague declaration: Towards an information literate society. National Commission on Library and Information Science; National Forum on Information Literacy \& UNESCO. Retrieved 15 October 2005 from: http://www.nclis.gov/libinter/infolitconf\&meet/postinfolitconf\&meet/post-infolitconf\&meet.html

National Forum on Information Literacy. Retrieved 15 October 2005 from: http://www.infolit.org/IAIL/

SCONUL Task Force on Information Skills (1999). Information Skills in Higher Education. London: Society of College, National and University Libraries.

UNE: Training of library Users in a New Europe. (2005) Ideas from café I: Competencies. Retrieved 15 October 2005 from: http://www.tune.eu.com/Power\%20Point/N-ideas-from-Cafe-I.pps

Virkus, S. (2003). Information literacy in Europe: a literature review. Information Research, 8(4), paper no. 159. Retrieved 10 October 2005 from: http://informationr.net/ir/8-4/paper159.html]

Webb, J. and Powys, C. (2004). Teaching information skills: theory and practice. London: Facet.

Johnston, B. and Webber, S. (2003). Information Literacy in Higher Education: a review and case study. Studies in Higher Education, 28 (3), 335-352.

\section{Web addresses of IL organisations (all retrieved 30 October 2005)}

ACRL Institute for IL:

http://www.ala.org/ala/acrl/acrlissues/acrlinfolit/professactivity/iil/welcome.htm

AlfinCat: http://www.cobdc.org/grups/alfincat/

ANZIIL: http://www.anziil.org/

CILIP CSG IL Group:

http://www.cilip.org.uk/specialinterestgroups/bysubject/informationliteracy

ENIL: http://www.ceris.cnr.it/Basili/EnIL/index.html

ENSIL: http://vs.eun.org/eun.org2/eun/en/vs-Library_vs/sub_area.cfm?sa=3937\&row=1

IFLA Information Literacy Section: http://www.ifla.org/VII/s42/index.htm

NORDINFOlit: http://www.nordinfolit.org/

SCONUL WGIL: http://www.sconul.ac.uk/activities/inf_lit/

Svensk Biblioteksförenings specialgrupp för bibliotekspedagogik:

http://www.biblioteksforeningen.org/ 


\section{APPENDIX, Participants of the workshops "Information Literacy and Learning"}

Leader of the Workshops

Sirje Virkus, Department of Information Studies, Tallinn University, Estonia, sirvir@tpu.ee

Experts of the Workshop Group

Albert K. Boekhorst, University of Amsterdam, The Netherlands; University of Pretoria, South Africa, A.K.Boekhorst@uva.nl

José A. Gomez-Hernandez, Library and Information Science Department, Faculty of Information and Communication Studies, University of Murcia, Murcia, Spain jgomez@um.es

Annette Skov, Royal School of Library and Information Science, Copenhagen, Denmark, AS@db.dk

Sheila Webber, Department of Information Studies, Sheffield University, United

Kingdom, s.webber@sheffield.ac.uk

\section{Experts of the Virtual Workshop Group}

Susie Andretta, Information Management School, London Metropolitan University, United Kingdom, s.andretta@,1ondonmet.ac.uk

David Bawden, Department of Information Science, City University London, United

Kingdom, db@soi.city.ac.uk

Sylvie Chevillotte, ENSSIB (Ecole Nationale Supérieure des Sciences de líInformation et des Bibliothèques), Villeurbanne, France, chevillo@enssib.fr

Bill Johnston, Centre for Academic Practice, the University of Strathclyde, United

Kingdom, B.Johnston@strath.ac.uk

Claire McGuinness, University College Dublin, Republic of Ireland,

claire.mcguinness@ucd.ie

Eva Ortoll Espinet, Universitat Oberta de Catalunya, IN3, Barcelona, Spain, eortoll@,uoc.edu

Cristóbal Pasadas Ureña, Faculty of Psychology, University of Granada, Granada, Spain, cpasadas@ugr.es

Margarita Perez-Pulido, Department of Informatics, University of Extremadura, Badajoz, Spain, marga@alcazaba.unex.es

Bernard Pochet, Gembloux Agricultural University, Belgium, Pochet.B@,fsagx.ac.be

Giovanni Solimine, Viterbo University, Viterbo, Italy, solimine@unitus.it

Tibor Koltay, Department of Information and Library Studies, Szent István University

Jászberényi College; Department of Library and Information Science Berzsenyi Dániel

College, Hungary, Koltay.Tibor@jfk.szie.hu

Paul Thirion, Faculty of Psychology and Education Science of the University of Liège, Belgium, paul.thirion@ulg.ac.be 